\title{
(Post)Modern Theology on Trial? Towards a Radical Theological Hermeneutics of Christian Particularity
}

\author{
Response to Anthony Godzieba and Laurence Hemming \\ Lieven Boeve*
}

Introduction

Not 'Too Much' but 'Too Little’ Recontextualisation

In their papers, Anthony Godzieba and Laurence Hemming confront Catholic theology with theological currents that take their point of departure in the postmodern critique of modernity, including, in Godzieba's words, critical correlationist theologies. Caputo's 'Derridean apophaticism' as well as Milbank's 'Radical Orthodoxy' challenge the new generation of Catholic theologians, not least because most of them have been trained and inspired by the great generation of theologians at work at Vatican II and/or in the making of post-Vatican II Catholic theology, namely, Karl Rahner, Edward Schillebeeckx, Hans Küng, Johann Baptist Metz and David Tracy, among others. In the spirit of Vatican II and its aggiornamento, these theologians entered into dialogue with modern society, science and culture. Today it would seem that this kind of theology has lost its plausibility and even its legitimacy, both inside and outside the Church.

The currents referred to above especially criticise the modern epistemological presumptions that underlie modern 'correlationist' theologies, which, therefore suffer from the same loss of plausibility as modernity itself. There is of course no offence involved in admitting that modern pre-

* A paper originally given at the Catholic Theological Society of America Annual Convention in Cincinnati in June 2003, as part of a trio of papers for the Postmodern Theology Working Group. 
sumptions - I would not call this a hidden complicity ${ }^{1}$ - are at work in modern theology. It would even be awkward if that were not the case. Just as Jesus, according to John Meier, was truly a Jew such that "the Word becomes truly Jewish," 2 modern theologians, reflecting on their faith and the faith of their communities, are modern. In the same vein, the youngest generation of theologians is postmodern - assuming that one accepts this category to adequately describe the current context and its sensibilities. Whatever the relation to one's context, one is irreducibly marked by it. Of course, these terms - Jewish, modern, and postmodern - still allow for a certain plurality, ambiguity, shifts in meaning, and thus, discussion. Nevertheless, they at least intend to hint at meaningful sets of family resemblances, enabling us to make, albeit rough, distinctions.

This being said, I would agree with these so-called postmodern theological currents, such as Radical Orthodoxy and the kind of negative theology Godzieba was criticising, that modern theology is no longer functional. However, this is not because it has never functioned (i.e., because it was a theological mistake), but because the context in and for which this theology has been conceived is no longer our context. Therefore, the fact that modern theology is outdated is not a denial of the general contextual rootedness of theology, nor of the hermeneutical turn in theology. ${ }^{3}$ On the contrary, it is its logical outcome, given that this context has changed - thus leading to more hermeneutics. So, criticising 'correlation' does not necessarily lead to abolishing the modern theological project by imposing a premodern theological rationality (a 'theoontology'4) onto philosophy, or by reducing the Christian religion to an apophatically structured 'religion without religion'. Rather, criticising 'correlation' provokes a new recontextualising, a renewal in the ongoing search for adequate ways in which the intrinsic bonds between faith, tradition and context can be thought of today - both according to contextual and theological standards. ${ }^{5}$

Therefore my thesis would be, against Radical Orthodoxy, but also against Derridean negative theology, that it is not 'too much' recontextualisation

1. Cf. in this volume Anthony J. Godzieba, "Incarnation, Theory, and Catholic Bodies: What Should Post-Postmodern Catholic Theology Look Like?," 217-231.

2. Cf. ibid., 226.

3. On this 'tournant herméneutique', see e.g., Claude Geffré, Croire et interpréter: Le tournant herméneutique de la théologie (Paris: Cerf, 2001).

4. See in this volume: Laurence Paul Hemming, "What Catholic Theologians Have to Learn from Radical Orthodoxy: What Radical Orthodoxy Has to Learn from Catholic Theology," 232-239.

5. For the category of recontextualisation, see my Interrupting Tradition, Louvain Theological and Pastoral Monographs, 30 (Leuven/Grand Rapids, MI: Peeters/Eerdmans, 2003), chapter 1 . 
that causes the problems in/of Catholic theology today, but 'too little' recontextualisation. Moreover, I would claim that Catholic theology today, because of its incarnational, sacramental character, must be a radical hermeneutical theology, starting from a full acceptance of the particularity, contingency and historicity of its tradition. Unlike the two currents under critique here, I would argue that thinking from this very particularity does not necessarily lead to the absolutising of a theological rationality (Radical Orthodoxy) or its imposition on an age in which rationality's standards have been downplayed and/or pluralised. Nor does it finally result in the evacuation of the irreducible cataphatic aspect of Christian tradition, implying a severe relativising of this particularity in order to come to a 'pure religion' - religion without religion - in 'pure prayer' (Caputo).

\section{Mirroring Questions for Hemming and Godzieba}

From Laurence Hemming ${ }^{6}$ I recall the distinction he makes between the discourses of philosophy and theology, the provinces of faith and reason (or is it better to say, regarding the latter, reason enlightened by faith). Nevertheless, I wonder how Hemming would see the relationship between faith and reason, theology and philosophy. We are well aware of the fact that Milbank and his colleagues use postmodern philosophical and theological thinking as witnesses of the dramatic outcome of secular modernity resulting in (perspective-less) nihilism. At this point, they introduce a kind of theo-ontology 'to save the appearances by exceeding them'. They opt for a participationist metaphysics that claims that the integrity of the finite can only be safeguarded by its participation in the infinite. (As a matter of fact, one could wonder whether Godzieba's term 'post-postmodern' would not better suit this position, rather than 'postmodern'.)

To come back to my question: After having distinguished faith and reason, and philosophy and theology, what is, then, the precise relationship between the two? Or, from the perspective of the recontextualisation urged today: How can postmodern philosophy help theology, beyond, as is the case in Milbank, doing deconstructive groundwork in order to prepare for the construction of a completely independent theological building (praeparatio theologiae)? How can it indeed assist in this constructive endeavour, sustaining the efforts to elaborate the rationality of faith, in which believers enter by taking the leap of faith (ancilla

6. Not being a specialist in Aquinas, I am not going to dispute Hemming's reading of the 'analogia entitatis', which would necessitate a response in its own right. 
theologiae)? The Church Fathers, medieval theologians, as well as modern theologians, used philosophy in the same way.

In a similar, though not perfectly analogous, direction also proceeds - and from this perspective even more urgently so - Godzieba's plea to make the particularity of revelation publicly and rationally accessible. In order to do so, Godzieba presents a 'thinking by means of the body' through the perspective of vulnerability and ontological frailty. This kind of thinking again would seem to invite the opportunity to claim the status of 'quasi-universality'. In dialogue with it, theology would seem to be able to re-establish its rationality, plausibility and legitimacy in relation to today's world. At least, according to Godzieba this is where the mutual supportive relationship of faith and reason should lead.

Of course, this question can be reversed. Hemming tried to explain that one could understand why analogia entis, though not in Aquinas, was a historical-theological necessity. It was used to solve philosophical problems in a time in which God came to occupy the centre of all human and thus also philosophical reflection. In the same way, one could argue that the modern correlation method, as a very specific way to structure the intrinsic relation between theology and context, was also a historicaltheological necessity. It tried to ground Christian faith in patterns conceived of as generally, universally human. The particularity of Christian faith was then no longer a hindrance to its truth claims, because this particularity was shown to be a specific filling in of universally acknowledgeable structures and often even the culmination or the fullest realisation thereof. Correlation, therefore, was an answer to a modern-contextual problem in which one could not think faith as faith. Always - and even in the anti-modern reactions - one deemed it necessary to search for firm foundations (in this regard Radical Orthodoxy as well, in its insistence on a theo-ontology which usurps philosophy, seems to follow the same line).

When one applies this to Godzieba's response to the crisis of modern theology, one is faced with the following question. In his attempt to locate 'thinking by means of the body', even when the body leads us 'to think otherwise', is there not already a claim of faith at work? Is Godzieba's preference for vulnerability and ontological frailty, and the potential these open for a link between theological discourse and a quasiuniversal anthropology, not already too heavily influenced by theological presuppositions? If so, then it would seem that the public communicative objective that he strives for with his theological discourse is ruled out from the very beginning, or at least highly problematic. Is there not already a very particular option involved by means of which Godzieba intends to make Christian faith quasi-universally accessible, through 
which he seeks to elaborate the rationality of faith within a new context - a rationality which, however, is only there because of faith? To specify my question: it seems that one would only be able to respect particularity when one can justify this respect through (quasi) universal thinking patterns; the particularity of Christian faith in the end would always need a rational quasi-universal back-up to sustain its truth claims.

However, would a contemporary theological thinking by means of the body not act in a more radically particular way? Christians only find truth in their particularity, not in spite of it. Narrativity, historicity, contingency, including ambiguity, messiness, conflicts, etc. are not contradictions of the truth of the Christian tradition, but the only way in which God's revelation takes shape - the only way in which God's Word becomes incarnate. And precisely acknowledging this, I would say, is entering into the logic of faith, a logic that is not devoid of rationality but introduces a theological rationality, installed and only to be acquired in faith. In the act of faith, it is then no longer the will which supplements what is hinted at by reason, but which opens up the space for a thinking which links 'God, human persons, and the world'.

To summarize my questions, I would ask Godzieba: Do you really respect 'faith' as 'faith'? And Hemming: Respecting faith as faith, where does that leave the role of contemporary philosophy in reflecting upon faith and developing its specific rationality - at least if one acknowledges that theology is involved in a continuing process of recontextualisation?

In line with the remarks I have made so far, it would seem that both Radical Orthodoxy and Derridean negative theology are symptoms rather than solutions to the problem of Catholic theology today. In order to hint at the way I would deal with the challenges of the current postmodern context for theology, I will comment briefly on both, starting with socalled Derridean negative theology, of which Jack Caputo would seem to be one of the most prominent representatives. In doing this, I shall attempt to answer the questions I have asked Godzieba and Hemming.

\section{Towards a Radical Theological Hermeneutics of Christian Particularity: Against its Relativization}

Godzieba, for his part, critiques Caputo's position ${ }^{7}$ for its evacuationist attitude vis-à-vis modernity, and denounces its anti-human

7. See e.g. John D. Caputo, The Prayers and Tears of Jacques Derrida: Religion without Religion (Bloomington, IN: Indiana University Press, 1997); More Radical 
character and especially its aversion to, or reduction of, any cataphatic dimension. In the end, the only remedy he proposes consists of taking an anti-deconstructionist stance. In my account, however, I would like to critique this position, not by opposing it as such, but by deconstructing it in its own right. ${ }^{8}$

The interest in Christian theology or Christian religion of some deconstructionists seems to result in a 'radical kind of reduction' of its very particularity. Such a radical reduction would not only reveal a general religious structure, which precedes all particularity and narrativity, but would open the possibility of a 'radical kind of spirituality' of 'pure prayer'. ' Relying on texts of the later Derrida, Caputo identifies 'pure prayer' with "an act directed at someone, at a 'you,' even and especially if one has no assurance that there is such a 'you'." ${ }^{10}$ More than being a method, deconstruction here takes the form of spirituality. In Caputo's account, Derrida's deconstructionism indeed seems to be turned into what could be qualified as a non-indifferent agnosticism: the passion for non-knowing results in a passionate refusal to choose between theism - relation with God - and atheism - auto-constitution. The outcome is a paradoxical attempt to retrieve the relational attitude which structures the subject in theism, but without the relationship itself - 'religion without religion'.

Others, like Hent de Vries, object to Caputo's reading of prayer in Derrida, and accentuate the fact that one cannot turn Derrida instantaneously into a 'man of prayer', because Derrida's prayer itself is in the last instance always suspended. There is no pure prayer without this prayer already having been contaminated. ${ }^{11}$

It would seem, however, that the objection of De Vries to Caputo - thus resulting in a double reading of the same Derridean texts - points

Hermeneutics: On Not Knowing Who We Are (Bloomington, IN: Indiana University Press, 2000); On Religion, Thinking in Action (London: Routledge, 2001).

8. For a more elaborated discussion of this kind of thinking, see my "The Rediscovery of Negative Theology Today: The Narrow Gulf between Theology and Philosophy," Théologie négative, ed. Marco M. Olivetti, Biblioteca dell'Archivio di Filosofia', 59 (Rome: CEDAM, 2002) 443-459.

9. See John D. Caputo, "Shedding Tears Beyond Being: Derrida's Experience of Prayer," Théologie négative, 861-880.

10. Ibid., 868.

11. Cf. Hent de Vries, Philosophy and the Turn to Religion (Baltimore, MD: The Johns Hopkins University Press, 1999) 139. See further p. 140: “[The passing moment of pure prayer] has no existence, no relevance or no effect, outside of the concrete prayers (or apophatic discourses) that it inaugurates, inspires, interrupts. It does not fall from heaven but remains, in a sense, parasitic upon or oriented toward the historical and positive determinations that it makes possible in the first place. More precisely still: it is made possible by what it makes possible. That is its aporia." 
beyond their discussion to the specific and inescapable ambiguity on which Derrida's position both thrives and to which it testifies. One cannot hold out the 'suspension' without already, while suspending, being narratively positioned. Both de Vries and Caputo then would accentuate one of the two sides of this ambiguity, leading de Vries to a more methodical reading of Derrida (deconstruction as a method) whereas Caputo offers us a kind of spiritual reading (deconstruction as a way of living).

We would like to extend this observation somewhat further. What should we think of the following suggestion? If one claims that in the end, the question cannot be decided, one has likewise taken an option in maintaining this inability to decide. Only from within language, from within particular vocabularies and thinking patterns can one evoke the limits of language. Seen from within their own traditions, deconstructive philosophy and Christian negative theology would seem rather to constitute two positions, each of which thinks from, and about, its being posited. ${ }^{12}$ Both would seem contextually embedded and narratively structured, particular discourses dealing with the 'otherness' which at the same time is constitutive for their discourse and escapes all attempts to be determined by it.

'How not to speak' both in Christian theology and philosophy then ultimately remains an exercise that is conditioned by its narrativity - irreducible but nevertheless to be suspended - and, therefore, by a radical hermeneutics. This is also true for Derrida and Caputo's reception. The attempt to think an appealing alterity or transcendence without God as différance is a very contextual and particular possibility open for thinkers in the decades before and after the turn to the third millennium. Indeed, how not to speak? The result is that we end up with two discourses, philosophy and theology, between which, notwithstanding some structural similarities, a différend exists. Likewise, as far as Christians are concerned, it is faith in the God Creator, Father, Son and Spirit, revealed in the history of Israel, it is Jesus confessed as the Christ, it is the church which

12. In his own reflections, Derrida makes a distinction between both, but sees deconstruction as capable of making this difference, thus deconstructing negative theology as posited, without highlighting as well deconstruction's being irreducibly posited. The prayer and the praise stand between deconstruction and negative theology - see Jacques Derrida, "Comment ne pas parler? Dénégations," in his Psychè: Inventions de l'autre, La philosophie en effet (Paris: Éditions Galilée, 1987) 535-595, p. 570; other texts of Derrida on this subject: Saufle nom (Paris, Éditions Galilée, 1993); "Foi et savoir: Les deux sources de la 'religion' aux limites de la simple raison," La religion: Séminaire de Capri, ed. Jacques Derrida \& Gianni Vattimo (Paris: Éditions du Seuil, 1996) 9-86. The first reference to the similarity and difference between deconstruction and negative theology dates back to a text from 1968: "La différance," published in Marges de la philosophie (Paris: Minuit, 1972) 6. 
is not of, yet in, the world of today, which make the difference. Moreover, the epistemological impact of Christian negative theology does not stem from an experience of the bankruptcy of human self-divination but rather from 'the Christian distinction,' i.e., the theological difference between creation and Creator. ${ }^{13}$ Taking Caputo's negative theology as a solution to the problems with which Catholic is faced today can hardly be considered as a fruitful solution. For this purpose it reflects too much a post-Christian spirituality, doing away with the irritating historical particularity of Christianity, the irreducible cataphatic dimension as witnessed to in the doctrine of the incarnation. The result is indeed a faith without faith. ${ }^{14}$

This is not to say that a fruitful encounter of theology and deconstruction is precluded from the very outset. Deconstruction, or more broadly, thinking difference, can indeed warn theology against falling too easily into the trap of onto-theology. In this regard, it can help the Christian tradition to rediscover - recontextualise ${ }^{15}-$ its own tradition of negative theology both as deconstruction of, and precondition for, the possibility of positive theology. Theologians can then learn that negative theology in the apophatic tradition is not only a supplement to positive theology - a sort of complementary relativisation - but rather the ongoing and requisite background of every positive statement about God. Negative theology, then, does not teach us the failure of religious language or its deficiency, but rather its structure, as a consequence of the 'Christian distinction'. ${ }^{16}$

It is this structure of religious language which teaches us that the cataphatic is not the 'contamination' of pure religion or pure prayer: Neither, as we will argue below, is it a theo-ontological framework usurping philosophical rationality. On the contrary, the cataphatic consists of the

13. As coined by Robert Sokolowski, The God of Faith and Reason: Foundations of Christian Theology (Notre Dame, IN: University of Notre Dame Press, 1982).

14. Ilse Bulhof as well seems to direct her reflections towards a 'Christianity without Christianity'; see e.g. her contributions to the volume she co-edited with Laurens ten Kate, Flight of the Gods: Philosophical Perspectives on Negative Theology, Perspectives in Continental Philosophy, 11 (New York: Fordham University Press, 2000) 1-57 (Bulhof \& Ten Kate), 195-222 (Bulhof), and 385-390 (Bulhof).

15. For the concept of recontextualisation from the viewpoint of the methodological mediation of philosophy in theology, see among others my "Method in Postmodern Theology: A Case Study," The Presence of Transcendence: Thinking 'Sacrament' in a Postmodern Age, ed. Lieven Boeve \& John C. Ries, Annua Nuntia Lovaniensia, 42 (Leuven: Peeters, 2001) 19-39; and "The Swan or the Dove? Two Keys for Reading Fides et Ratio," Philosophy and Theology 12 (2000) 3-24.

16. An attempt to do theology in this regard is offered by Kevin Hart in The Trespass of the Sign (Cambridge: Cambridge University Press, 1989, 22000). 
very particular narratives and discourses in which believers confess their faith in the God they come to know and to believe in through these very narratives and discourses. In the processes of being handed down and structuring the lives of believers and their communities, these narratives and discourses (both consciously and unconsciously) are recontextualised, in a continuous attempt to testify to the Christian distinction.

\section{Towards a Radical Theological Hermeneutics of Christian Particularity: Against its Absolutisation}

In the autumn of 1999, at the second LEST-congress on 'Sacramental Presence in a Postmodern Context', Graham Ward addressed the topic of Eucharistic Presence. ${ }^{17}$ In doing so he gave a typical illustration of the method of Radical Orthodoxy. ${ }^{18}$ After having elaborated how presence was thought in Aquinas (informed by Augustine), Ward subsequently showed that in early modernity the intellectual environment shifted - i.e. pre-modern 'theo-ontology' slips into modern ontotheology - so that 'eucharistic presence' could not be thought of anymore. Secondly he explained, using the thinking patterns of the Croatian thinker Zizek, why the postmodern critique of metaphysics, itself a radicalisation of modern premises, does not offer any solution, because of its taking as its point of departure an 'economy of lack'. In a third step, Ward developed what one could call a 'postmodern critical Augustinian' stance. Presence, thus also Eucharistic presence, does not vanish in an immanentistic play of signs, nor is it reduced to a traumatic, eventful in-breaking of transcendence into a world enclosed in itself. Rather it is the presence in the 'now' immediately related to the eternal. "The present is not a discrete and isolatable entity, as Augustine reminds us." For such a view implies a 'violation of time'. For Augustine, the now always recollects the past and looks ahead to the future - it participates in an encompassing continuity, exceeding the present. "For the Eucharist participates in a temporal plenitude that gathers up and rehearses the past, while

17. Published in the proceedings of this second conference in the Leuven Encounters in Systematic Theology: Graham Ward, "The Church as the Erotic Community," Sacramental Presence in a Postmodern Context: Fundamental-Theological Approaches, ed. Lieven Boeve \& Lambert Leijssen, Bibliotheca Ephemeridum Theologicarum Lovaniensium, 160 (Leuven: Peeters, 2001) 167-204.

18. This is to say: at least of its main protagonists because supporters as well as critics continually deem it necessary to accentuate the heterogeneity of stances within the latter movement. 
drawing upon futural expectations and significations of the act in the present." 19 In the words of the "Introduction" to the volume Radical Orthodoxy: "The theological perspective of participation saves the appearances by exceeding them." ${ }^{20}$ In his response to Ward, Kevin Hart brought - among other comments - two elements to my attention, on which I would like to elaborate. First, he denounced Radical Orthodoxy's onesided reading of Western intellectual history, especially of modernity, which is portrayed as leading to secularism, and postmodernity, which results in nihilism, both of which today's theology should overcome. Secondly, he criticised the selective, quasi ahistorical, reading of Christian tradition, favouring one tradition over other traditions, thereby adopting explicit Patristic schemes involving high Trinitarian and Christological speculation.

These comments reflect two very specific methodological choices of John Milbank and some of his colleagues in Radical Orthodoxy, as well as, some criticisms of those choices. I will subscribe to those criticisms and will try to motivate them from the theological-methodological point of view already advocated above, which both urges a new dialogue of the Christian tradition with the postmodern context, and is already informed by it. As my point of departure, I take Milbank's programmatic article "Postmodern Critical Augustinianism: A Short Summa in 42 Responses to Unasked Questions." 21 In the first seven paragraphs, postmodern theology is sketched as the reflexive explicitation of Christian practice, as performed by and constitutive of Christian faith communities. Theology as fides quaerens intellectum is profiled in a context that has become conscious of the plurality of fundamental life options and religions, and aware of the dynamic, often conflictuous interplay of the constituents of this plurality, challenging each other by their very otherness. Moreover, plurality and the confrontation with otherness have made explicit the very particularity, contextuality and historicity of one's own fundamental life option. For Christians, this is their Christian narrative, the Christian tradition as it is lived and reflected upon here and now. Doing theology in a postmodern context then indeed refers theologians back to

19. Ward, "The Church as the Erotic Community," 191.

20. "Introduction," Radical Orthodoxy: A New Theology, ed. John Milbank, Catherine Pickstock, Graham Ward (London/New York: Blackwell, 1999) 4.

21. This article appeared in Modern Theology 7 (1991) 225-237. Milbank is of course also the author of, e.g., Theology and Social Theory: Beyond Secular Reason (Oxford: Blackwell, 1990) and The Word Made Strange: Theology, Language, Culture (Oxford: Blackwell, 1997), and, with Catherine Pickstock, Truth in Aquinas (London: Routledge, 2001). 
the very concrete and particular narrativity of their faith praxis and faith communities, situated in and challenged by the otherness of other particularities. So far I can enthusiastically subscribe to everything said. However, it is from $\$ 8$ on that John Milbank makes at least two decisions which affect the outlook of his postmodern theology to such an extent that our theological approaches go in very different directions: ${ }^{22}$

(1) As regards the first decision, plurality seems to imply, according to Milbank, that every practice or discourse, among them Christianity, is on the same level - plurality would thus appear to lead immediately to pluralism and thus to relativism. Everything is, although different, more of the same. As a matter of fact, this move is paralleled by the immediate shift Milbank appears to make from postmodernity (adjective 'postmodern' - as a descriptive category) to postmodernism (which is identified with a positive 'embracing of contingency and arbitrariness as the real natural good', thus with 'nihilism'). Postmodernism, pluralism, nihilism - all are categories to identify a way to deal with, to embrace, the differential flux - and this is also the case for Christianity. Plurality, in the end, seems to be a plurality of two - a duality (which could well turn into a dualism): it is either nihilism or Christianity.

(2) And here the second decision comes into play. Christianity is indeed a different way to deal with this flux - a way which cannot allow itself to be reduced to the same level. This is because of the all-encompassing horizon of harmony that determines the way in which Christianity deals with difference. Music then serves as the metaphor, the paradigm, to both evoke and clarify this harmony without violence and conflict. Christian particularity becomes here Christian singularity, placed in opposition to 'postmodernism'. Christian theology thus deals with what it is to be a true, God-like community $(\$ 11)$. It deals with the heavenly city, of which the substantial peace can also be "imperfectly present in the fallen world, in the sequences of time, and time redeemed through memory" $(\$ 15)$. Here, again, Augustine's approach to time comes into play. Postmodernist accounts of difference involve conflict, violence, exclusion, and dualism. The Christian account subsumes difference under a horizon of peace and harmony.

These two interrelated decisions should not be overlooked too easily, because the consequences are immense, both for theology and philosophy, and especially for the interplay between the two. In reverse order:

22. For it would seem that Milbank's position indeed is no longer really 'postmodern' - except if one interprets the prefix 'post' in a merely chronological way, and then, of course, as already mentioned, the term 'post-postmodern' would more accurately describe his approach. 
first, there is the reduction of Christianity to theological-philosophical Augustinianism, and, secondly, theology, as the reflexive account of Christianity, is profiled in a context of relativism and nihilism, as the vera philosophia, the only way to overcome pluralism and nihilism. As stated in the introduction to Radical Orthodoxy: the finite only preserves its own integrity - in fact, even its worldliness - when it participates in its infinite eternal source. In modern epistemology and postmodern nihilism, on the contrary, the integrity of the finite ultimately dissolves. ${ }^{23}$

What is at work here is a too hasty identification of philosophy and theology. Left to itself, postmodernist philosophy evacuates theology (shown, for example, in the reception of Derrida and others by thinkers such as Don Cupitt, Marc Taylor, and John Caputo). And John Milbank is right when he asks whether one can really worship transgression, différance, the differend, indifferent otherness, and so on. But to prevent the annihilation of theology by postmodernism, he then proposes to evacuate or usurp philosophy by installing a theological rationality of a specific kind, a Platonist Augustinian participationist theo-ontology. It remains a question, however, whether this strategy is, philosophically speaking, the best solution to offer. One really wonders whether it is necessary to strive after a (Platonist-Augustinian) metaphysics, or to use JeanFrançois Lyotard's term, a Platonist-Augustinian grand or master narrative, in order to overcome nihilism. Theologically speaking, Milbank is claiming that only a metaphysically secured Christian faith will survive the modern crisis of secularism and the postmodern crisis of nihilism.

This begins already with Milbank's decision to analyse plurality immediately in terms of pluralism and relativism. One easily could make a link here to the theological pluralist/anti-pluralist debate as to whether the incarnation of Christ is a myth or metaphor, or as to what really makes the difference between Christianity and the other world religions. For John Hick, one of the pluralist protagonists, all religions can be considered as modes of relating to 'the Real', that which we encounter in religious mystical experience - prior to every conceptuality - the 'ineffable'. Religions are thus 'on a level', ultimately reducible to narrative, historical-contextual particularizations of a structure that can be traced with reasonable certainty. ${ }^{24}$ It would seem that we are dealing here with a modern epistemological observer's position, reducing the plurality of religions in a new sort of modern apologetic in order to protect it (in the

23. Milbank, Pickstock, Ward, Radical Orthodoxy, 4.

24. For a more extensive evaluation of Hick's position, see: Terrence Merrigan, "Religious Knowledge in the Pluralist Theology of Religions," Theological Studies 58 (1997) 686-707, pp. 695-696. 
first instance against the absolute claims of Christianity). But is John Milbank not doing the reverse: namely, reducing the plurality to 'more of the same' to secure Christianity's truth claim? This would imply that Milbank also sticks to the epistemological observer's position.

From this discussion, it would appear that theologians only have the choice between the grand narrative of pluralism and relativism, and the Christian grand narrative. One must wonder whether this is really the case. On the contrary, it is quite legitimate to suppose that a dialogue with contemporary philosophy (and the other religions) would teach theology not to forget its own particularity too easily, its own stance as a participant in the field of religions and fundamental life options. This dialogue could warn theology not to adopt a self-proclaimed observer's position, which so easily gives rise to totalitarian and exclusivist attitudes. Of course, this would imply the necessity for contemporary theology, in a dialogue with the diverse voices of philosophy, to reconceptualise its truth claim - which is however not the same as abandoning it. Instead of condemning the renewed sensitivities to plurality and otherness in terms of nihilism and relativism, such an effort urges a serious taking into account of the irreducible plurality of always particular narratives, religions, fundamental life options, as a starting point. To this plurality Christianity is inescapably related as a co-participant, living up to the truth of its tradition. Christians start to reflect on this from their own particularity, marked by the narrative community they live in, situated in and not separated from the world of many voices and truth claims $s^{25}$ - a world which as far as John Milbank is concerned can only be approached in terms of fallenness, sin, and evil.

The latter brings us to John Milbank's second decision: the reductive identification of theology, as a reflection upon Christian practice, with a Platonist-Augustinian theo-centred metaphysics. In my opinion, this reduction de facto - and contrary to John Milbank's own intention (harmony) - results in a dualism between church and world, Christianity and the others, the history of salvation and the history of struggle,

25. I tentatively elaborated on the consequences of the postmodern condition of irreducible plurality and otherness, in "The Particularity of Religious Truth Claims: How to Deal with it in a So-called Postmodern Context," Truth: Interdisciplinary Dialogues for a Pluralist Age, ed. Kristin De Troyer \& Christine Helmer, Studies in Philosophical Theology, 22 (Leuven: Peeters, 2003) 181-195. In an extensive research project, which I direct together with Mathijs Lamberigts and Terrence Merrigan, entitled: Orthodoxy: Process and Product, sponsored by the Research Fund of the K.U. Leuven (2003-2007), this attempt at reconceiving contemporary theological epistemology is undertaken. Another research project on Radical Orthodoxy, granted by the Fund for Scientific Research of Flanders (F.W.O.) has been initiated in this framework: Postmodern NeoAugustianism: Old Wine in New Vessels? (Lieven Boeve \& Mathijs Lamberigts, 20042007). 
conflicts and suffering. That the first element is always developed against the second element, which then in turn can only be 'saved' by inclusion in the first element, results from the first decision John Milbank took. What is of concern regarding the second decision now, is his a-historical, a-hermeneutical, selective retrieval of Christian tradition, and his profiling of it as the Christian theology for today. Milbank seems to have no difficulty at all with a rather massive use of concepts such as "the doctrine of the Trinity," "the doctrine of Incarnation," "the doctrine of the Church." It is as if these concepts are self-evident truths, embedded in a corpus of Christian truths, once and for all fixed and available. It is as if these concepts do not refer to historically and contextually embedded propositions of faith, and are not attempts to evoke the mystery of faith which the community of the faithful professes. As a matter of fact, such a procedure gives rise too easily to an extremely high doctrine of the Trinity, an extremely high christology and ecclesiology. Unless this situatedness of both first-order and second-order discourses (confessional and dogmatic respectively) is taken into account, and a serious hermeneutical attempt is undertaken to retrieve what is at stake in these discourses, theology risks drying up in a rather sterile repetition of phrases which are disconnected from the faith community which lives in the world of today - rather than being a lively and plausible reflection of lived faith and faith-community today.

At the heart of Christian faith, and thus of theology, lies the confession that, in Jesus Christ, God revealed Godself definitively as Love, as a promise to human beings, to the world, to history. The way in which this confession is evoked, made explicit, and thought of, is irreducibly bound to the contexts in which Christians and their communities confess their faith. And when, in the course of history, these contexts shift, then tradition recontextualises itself as well. With the Cappadocians and Augustine, this theological recontextualisation was undertaken in an intense dialogue with middle and neo-Platonist thinking. Thomas Aquinas was challenged by the rediscovery of Aristotle. Rahner and Schillebeeckx, one could argue, confronted theology with impulses stemming from the first and the second critique of Kant, respectively. Has theology's encounter with philosophy really stopped with the Patristics, with Thomas Aquinas - before Scotism? Or is it again our urgent task as theologians to engage in a recontextualisation process with the philosophies of our times? Of course, this does not mean to merely adapt Christianity to postmodernism, or to baptise the same postmodernism as cryptotheology. These are, indeed, traps into which some correlationist theologies have fallen. But it also does not mean stopping this dialogue at 
its beginning, presuming that only a slipping into nihilism will be the outcome. Recontextualising theology today means taking seriously the postmodern criticism of master narratives, of the deconstruction of selfsecuring truth claims. It is the challenging attempt to cope with the critical consciousness of our time that reveals to us the very particularity of the Christian tradition. ${ }^{26}$ But, as in the past, it also enables us to rediscover and express - with the help of contemporary philosophical categories and thinking patterns - once again the mystery of the faith we Christians profess today - just as Augustine and Thomas Aquinas did in their day.

Lieven Boeve is professor of fundamental theology at the Faculty of Theology, K.U. Leuven, and the co-ordinator of the Research Group Theology in a Postmodern Context (http://www.theo.kuleuven.ac.be/ogtpc/). His research concerns theological epistemology, religious experience, truth in faith and theology, tradition development and hermeneutics. Recently he authored Interrupting Tradition: An Essay on Christian Faith in a Postmodern Context, Louvain Theological and Pastoral Monographs, 30 (Leuven/Grand Rapids, MI: Peeters/Eerdmans, 2003), and edited with L. P. Hemming the volume Divinising Experience: Essays in the History of Religious Experience from Origen to Ricour, Studies in Philosophical Theology, 23 (Leuven: Peeters, forthcoming). Address: Faculty of Theology, Sint-Michielsstraat 6, B-3000 Leuven.

26. See, e.g., my "Critical Consciousness in the Postmodern Condition: A New Opportunity for Theology?," Philosophy and Theology 10 (1997) 449-468; and my cultural-theological essay, Interrupting Tradition (n. 5). 